\title{
Oceanithermus desulfurans sp. nov., a novel thermophilic, sulfur-reducing bacterium isolated from a sulfide chimney in Suiyo Seamount
}

Correspondence

Satoshi Hanada

s-hanada@aist.go.jp
Koji Mori, ${ }^{1,2}$ Takeshi Kakegawa, ${ }^{3}$ Yowsuke Higashi, ${ }^{1}$ Ko-ichi Nakamura, ${ }^{4}$ Akihiko Maruyama ${ }^{1}$ and Satoshi Hanada ${ }^{1}$

\author{
${ }^{1}$ Institute for Biological Resources and Functions, National Institute of Advanced Industrial \\ Science and Technology (AIST), Tsukuba Central 6, 1-1-1 Higashi, Tsukuba, Ibaraki \\ 305-8566, Japan \\ ${ }^{2}$ Biological Resource Centre (NBRC), National Institute of Technology and Evaluation (NITE), \\ 2-5-8 Kazusakamatari, Kisarazu, Chiba 292-0818, Japan \\ ${ }^{3}$ Graduate School of Science, Tohoku University, Sendai, Miyagi 980-8578, Japan \\ ${ }^{4}$ Institute for Marine Resource and Environment, National Institute of Advanced Industrial \\ Science and Technology (AIST), Tsukuba Central 7, 1-1-1 Higashi, Tsukuba, Ibaraki \\ 305-8567, Japan
}

Deep-sea hydrothermal vents have been discovered globally. In such environments, there are the peculiar ecosystems that are completely independent of sunlight and which include thermophilic chemoautotrophs as primary producers. Chimney structures and neighbouring sulfide mounds in hydrothermal areas are able to support metabolically diverse micro-organisms because of the fact that mixing of reduced hydrothermal fluid with oxic deep-sea water provides sharp physical and chemical gradients. Culture-independent analyses based on a $16 \mathrm{~S}$ rRNA gene clone sequence revealed that various micro-organisms inhabit such environments (Corre et al., 2001; Marteinsson et al., 1995; Takai \& Horikoshi, 1999; Takai et al., 2001, 2003). In recent years,

Published online ahead of print on 5 March 2004 as DOI 10.1099/ ijs.0.02962-0.

The GenBank/EMBL/DDBJ accession number for the 16S rRNA gene sequence of strain $\mathrm{St5}_{5} \mathrm{~B}^{\mathrm{T}}$ is $\mathrm{AB} 107956$. many novel thermophilic bacteria have been found in and around these hydrothermal vents (Alain et al., 2002b; Götz et al., 2002; Huber et al., 2002; Jeanthon et al., 2002; Miroshnichenko et al., 2003a, b; Nakagawa et al., 2003; Sako et al., 2003; Vetriani et al., 2004; Wery et al., 2001).

Investigations of thermophilic isolates in the domain Bacteria have focused on chemoautotrophs (e.g. oxidizers of hydrogen and sulfur compounds and anaerobes that reduce sulfur and nitrogen compounds). The ecosystem in hydrothermal vents does not consist solely of chemoautotrophs, but probably contains many heterotrophic thermophiles as decomposers or scavengers. In fact, many novel chemoheterotrophic bacteria have been isolated recently from hydrothermal environments. Among the heterotrophs isolated are three species belonging to the family Thermaceae: Marinithermus hydrothermalis (Sako et al., 2003), Oceanithermus profundus (Miroshnichenko et al., 2003a) and Vulcanithermus mediatlanticus (Miroshnichenko 
et al., 2003b). These novel species of the Thermaceae, recently proposed in rapid succession, are all 'true' marine organisms that require $\mathrm{NaCl}$ for growth. Before these marine species were found, all species in this family (belonging to the genera Thermus and Meiothermus) were inhabitants of freshwater environments, or were isolated from marine environments but were merely halotolerant and not halophilic (Marteinsson et al., 1995). These marine species were rod-shaped micro-organisms able to grow by respiration with oxygen as a terminal electron acceptor. However, the two species $O$. profundus and $V$. mediatlanticus are relatively sensitive to oxygen, and grow well at oxygen concentrations of less than $6 \%(\mathrm{v} / \mathrm{v})$ and $4-8 \%(\mathrm{v} / \mathrm{v})$, respectively (Miroshnichenko et al., 2003a, b). The microaerophiles are also able to use nitrate as an electron acceptor under anaerobic conditions.

Recently, a novel thermophilic, sulfur-reducing bacterium, designated strain $S t 55 B^{\mathrm{T}}$, was isolated from a chimney in a vent deposit sample in a submarine hydrothermal field. The chimney sample containing strain $\mathrm{St} 55 \mathrm{~B}^{\mathrm{T}}$ was collected from Suiyo Seamount in Izu-Bonin Arc, Western Pacific $\left(28^{\circ} 34^{\prime} \mathrm{N} 140^{\circ} 39^{\prime} \mathrm{E}\right.$; depth, $\left.1380 \mathrm{~m}\right)$ by the vessel ROV Hakuyo 2000 (Shin Nippon Kaiji) on 9 August 2001. The chimney sample was approximately $50 \mathrm{~cm}$ in diameter and $30 \mathrm{~cm}$ in length. A black smoker $\left(300^{\circ} \mathrm{C}\right)$ was discharging from this chimney. Mineralogical zoning was recognized in this chimney sample: the central part is essentially composed of chalcopyrite $\left(\mathrm{CuFeS}_{2}\right)$, the middle part is composed of sphalerite $(\mathrm{ZnS})$, pyrite $\left(\mathrm{FeS}_{2}\right)$ and anhydrite $\left(\mathrm{CaSO}_{4}\right)$, while sphalerite and pyrite are essential constituents of the outer part, together with arsenic sulfides. Elemental sulfur was also found in the middle and outer parts by X-ray diffraction analyses. The middle part of this chimney was used for this study.

For enrichment, vials (each with a butyl-rubber stopper and an aluminium cap) with basal medium were used. The basal medium under a $\mathrm{N}_{2} / \mathrm{CO}_{2}(4: 1, \mathrm{v} / \mathrm{v})$ atmosphere was composed of the following $\left(1^{-1}\right): \mathrm{KH}_{2} \mathrm{PO}_{4}, 0.75 \mathrm{~g}$; $\mathrm{K}_{2} \mathrm{HPO}_{4}, 0 \cdot 78 \mathrm{~g} ; \mathrm{MgCl}_{2} \cdot 6 \mathrm{H}_{2} \mathrm{O}, 0 \cdot 36 \mathrm{~g} ; \mathrm{CaCl}_{2} \cdot 2 \mathrm{H}_{2} \mathrm{O}, 0 \cdot 1 \mathrm{~g}$; $\mathrm{NH}_{4} \mathrm{Cl}, 0.54 \mathrm{~g} ; \mathrm{NaHCO}_{3}, 5 \mathrm{~g} ; \mathrm{NaCl} 30$ g; trace-element solution DSM 334 (DSMZ, 1993), $10 \mathrm{ml}$; vitamin solution DSM 141 (DSMZ, 1993), $10 \mathrm{ml}$. A fragment of the chimney was incubated at $55-85^{\circ} \mathrm{C}$ in the enrichment medium, which was basal medium supplemented with sulfur $\left(10 \mathrm{~g} \mathrm{l}^{-1}\right)$ and yeast extract $\left(2 \mathrm{~g} \mathrm{l}^{-1}\right)$, and supplied with $\mathrm{O}_{2} \quad\left(\mathrm{~N}_{2} / \mathrm{CO}_{2} / \mathrm{O}_{2}, 75: 20: 5\right.$, by vol.). After a 1-week incubation, growth of micro-organisms was observed at $55^{\circ} \mathrm{C}$; the culture was transferred to fresh enrichment medium several times. A similar enrichment medium solidified with $2 \%(\mathrm{w} / \mathrm{v})$ agar was used for isolation. An inoculated agar plate was incubated at $55^{\circ} \mathrm{C}$ in a sealed nylon bag with an oxygen-absorbing agent (Anaero Pack Campylo; Mitsubishi Gas Chemical Co.) for microaerophiles. Colourless colonies formed on the agar plate after 4 days incubation; strain $\mathrm{St} 55 \mathrm{~B}^{\mathrm{T}}$ was then isolated. The isolate was generally maintained in basal medium supplied with 2 g yeast extract $\mathrm{l}^{-1}$ and $20 \mathrm{mM}$ sodium nitrate under anaerobic conditions (see below).

Strain St $55 \mathrm{~B}^{\mathrm{T}}$ was characterized morphologically as comprising non-motile rods (about $0.5 \mu \mathrm{m}$ wide and $1 \cdot 5-2 \cdot 0 \mu \mathrm{m}$ long; Fig. 1a, b). Occasionally (at exponential phase under good growth conditions), cells tended to connect to each other forming chain-linked circular structures, called 'rotund bodies', that are often observed in some species of the genus Thermus (Brock \& Edwards, 1970) and in O. profundus (Miroshnichenko et al., 2003a) (Fig. 1c, d). The isolate had negatively Gram-stained cells with a thick cell-wall structure (Fig. 1b, d). Spore formation and pigmentation were not observed. Oxidase and catalase activities (Tamaki et al., 2003) were positive and weakly positive, respectively. However, when strain $S t 55 B^{T}$ grew anaerobically with nitrate as an electron acceptor (see below), oxidase was not produced.

An almost complete 16S rRNA gene sequence (Hattori et al., 2000) of strain $S t 55 B^{T}$ was determined (AB107956). After alignment with the ARB program (http://www.arb-home.de/), the phylogenetic tree (Fig. 2) was constructed by the neighbour-joining method with the CLUSTAL $\mathrm{W}$ program (Saitou \& Nei, 1987; Thompson et al., 1994). Strain St55B ${ }^{\mathrm{T}}$ was found to be a member of the family Thermaceae in the phylum 'Deinococcus-Thermus' and was very close to $O$. profundus (Miroshnichenko et al., 2003a), with a sequence similarity of $99 \cdot 5 \%$.

Strain $\mathrm{St} 55 \mathrm{~B}^{\mathrm{T}}$ could grow by oxygen respiration but did not support itself in an atmosphere of air (20\%, v/v, oxygen). The isolate was not able to form colonies at oxygen concentrations above $5 \%(\mathrm{v} / \mathrm{v})$; colony formation was observed at concentrations between 1 and $3 \%(\mathrm{v} / \mathrm{v})$. Although no fermentative growth was observed, the isolate showed good growth under anaerobic conditions in the presence of a suitable electron sink. Tests for utilization of electron acceptors in the presence of yeast extract $\left(2 \mathrm{~g} \mathrm{l}^{-1}\right)$ as a substrate (Hattori et al., 2000) revealed that the isolate could use nitrate $(5 \mathrm{mM})$, nitrite $(2.5 \mathrm{mM})$ and elemental sulfur $\left(10 \mathrm{~g} \mathrm{l}^{-1}\right)$ as electron acceptors in place of oxygen. However, it could not grow with the following acceptors: sulfate $(5 \mathrm{mM})$, thiosulfate $(5 \mathrm{mM})$, sulfite $(2.5 \mathrm{mM})$, DMSO $(5 \mathrm{mM})$, fumarate $(5 \mathrm{mM}), \mathrm{Fe}(\mathrm{III})$ citrate $(5 \mathrm{mM})$ (Heising et al., 1999) and selenate (5 mM). The culture with elemental sulfur showed slow growth, but sulfur certainly supported growth under anaerobic conditions. Miroshnichenko et al. (2002) reported that O. profundus could not use elemental sulfur as an electron acceptor. However, we also observed faint growth of $O$. profundus in our basal medium supplemented with elemental sulfur $\left(10 \mathrm{~g} \mathrm{l}^{-1}\right)$, sucrose $(10 \mathrm{mM})$ and yeast extract $\left(0 \cdot 1 \mathrm{~g} \mathrm{l}^{-1}\right)$. The turbidity of the culture was apparently lower than that of a culture with nitrate or oxygen as an electron acceptor; growth of $O$. profundus on elemental sulfur was similar to that in strain $\mathrm{St} 55 \mathrm{~B}^{\mathrm{T}}$.

The isolate required a small amount of yeast extract 

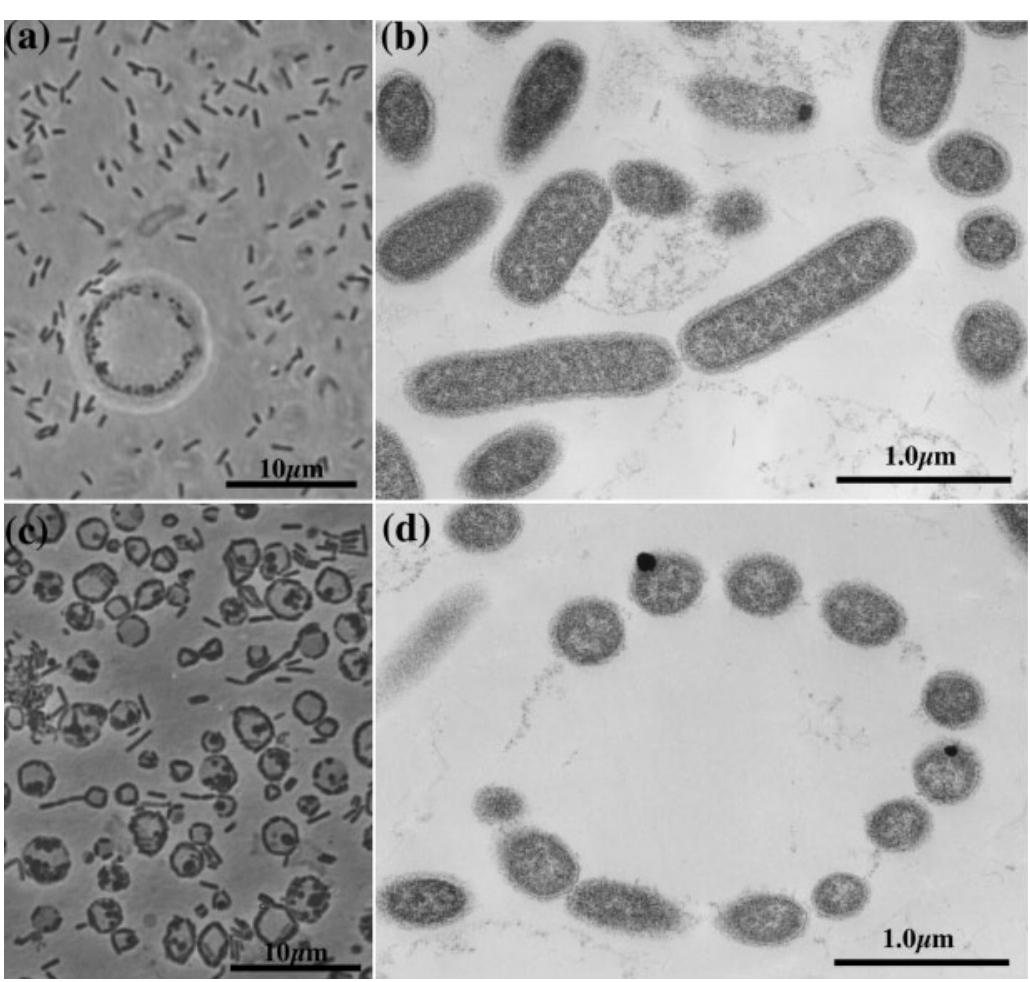

(d)
Fig. 1. Cell morphology of strain $S t 55 B^{\top}$ grown on yeast extract and nitrate (at $60^{\circ} \mathrm{C}$

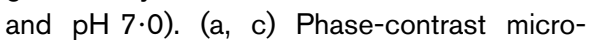
graphs of strain $\mathrm{St}^{2} 5 \mathrm{~B}^{\top}$. (b, d) Ultrathin sections of strain $\mathrm{St} 55 \mathrm{~B}^{\top}$, observed with a transmission electron microscope (model $\mathrm{H}$ 7000; Hitachi) (Hattori et al., 2000). 'Rotund bodies' were observed in a well-grown culture at exponential phase (c, d). Bars, $10 \mu \mathrm{m}(\mathrm{a}, \mathrm{c})$ and $1.0 \mu \mathrm{m}(\mathrm{b}, \mathrm{d})$.

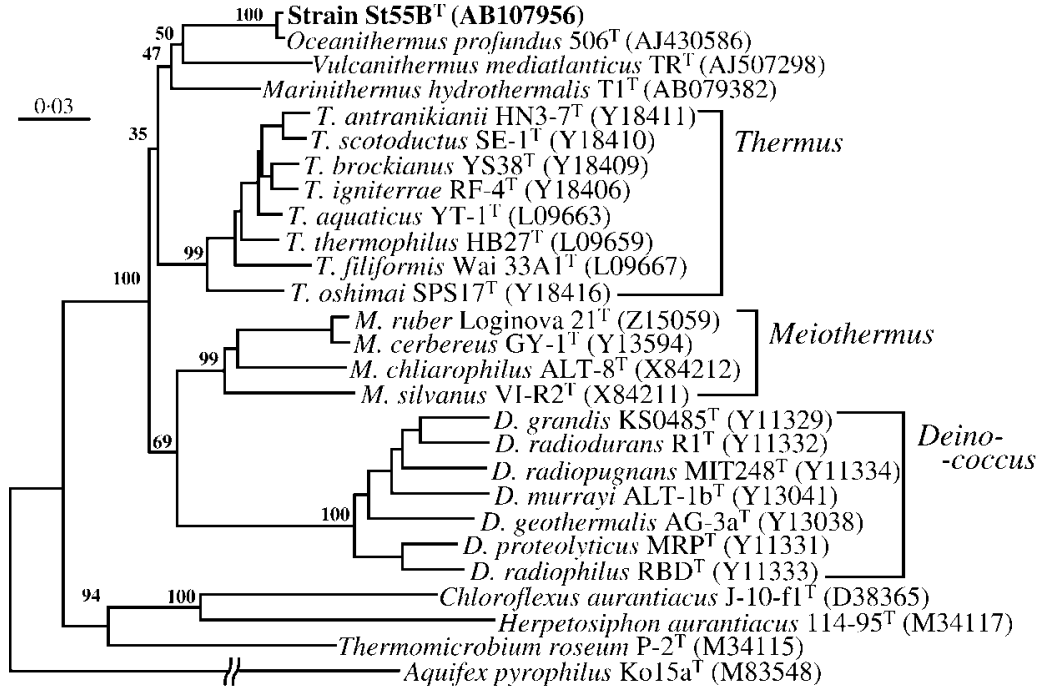

Fig. 2. Phylogenetic tree based on $16 \mathrm{~S}$ rRNA gene sequences of strain $S t 55 B^{\top}$ and relatives. Bootstrap percentages are indicated at branch points. Accession numbers of reference sequences are shown in parentheses. Bar, 0.03 substitutions per compared nucleotide. $\left(0 \cdot 1 \mathrm{~g} \mathrm{l}^{-1}\right)$ for growth under any growth conditions. In the presence of $5 \mathrm{mM}$ nitrate and $0 \cdot 1 \mathrm{~g}$ yeast extract $1^{-1}$, the isolate grew on each of the following as a sole source of energy and carbon: yeast extract $\left(1 \mathrm{~g} \mathrm{l}^{-1}\right)$, tryptone $\left(1 \mathrm{~g} \mathrm{l}^{-1}\right)$, Casamino acids $\left(1 \mathrm{~g} \mathrm{l}^{-1}\right)$, butyrate $(20 \mathrm{mM})$, formate $(40 \mathrm{mM})$, glutamate $(20 \mathrm{mM})$, lactate $(20 \mathrm{mM})$, propionate $(20 \mathrm{mM})$, pyruvate $(20 \mathrm{mM})$, succinate $(20 \mathrm{mM})$, L-alanine $(20 \mathrm{mM})$ and L-cysteine $(20 \mathrm{mM})$. The following substrates could not support growth: $\mathrm{H}_{2}$ / $\mathrm{CO}_{2}(4: 1, \mathrm{v} / \mathrm{v})$, acetate $(40 \mathrm{mM})+\mathrm{H}_{2} / \mathrm{CO}_{2}(4: 1, \mathrm{v} / \mathrm{v})$, arabinose $(10 \mathrm{mM})$, fructose $(10 \mathrm{mM})$, galactose $(10 \mathrm{mM})$, glucose $(10 \mathrm{mM})$, inositol $(10 \mathrm{mM})$, mannose $(10 \mathrm{mM})$, raffinose $(10 \mathrm{mM})$, sucrose $(10 \mathrm{mM})$, xylose $(10 \mathrm{mM})$, acetate $(20$ and $40 \mathrm{mM})$, citrate $(20 \mathrm{mM})$, fumarate $(20 \mathrm{mM})$, malate $(20 \mathrm{mM}), \quad$ L-arginine $(20 \mathrm{mM}), \quad$ L-asparagine (20 mM), L-histidine $(20 \mathrm{mM})$, L-leucine $(20 \mathrm{mM})$, Lmethionine $(20 \mathrm{mM})$, L-serine $(20 \mathrm{mM})$, ethanol $(20 \mathrm{mM})$, 2-propanol (20 mM) and methanol $(20 \mathrm{mM})$.

Temperature, $\mathrm{pH}$ and $\mathrm{NaCl}$-concentration ranges for growth were determined using $25 \mathrm{ml}$ Hungate tubes containing $10 \mathrm{ml}$ medium (Hattori et al., 2000). The medium contained $2 \mathrm{~g}$ yeast extract $1^{-1}$ as an energy source and $20 \mathrm{mM}$ nitrate as an electron acceptor under 
$\mathrm{N}_{2} / \mathrm{CO}_{2}(4: 1, \mathrm{v} / \mathrm{v})$. The temperature for growth of strain St $55 \mathrm{~B}^{\mathrm{T}}$ ranged from 30 to $65^{\circ} \mathrm{C}$, with an optimum at $60^{\circ} \mathrm{C}$. The $\mathrm{pH}$ range for growth at $60^{\circ} \mathrm{C}$ was $6 \cdot 0-8 \cdot 0$, with an optimum at $\mathrm{pH} 6 \cdot 5$. The isolate required $\mathrm{NaCl}$ for growth and grew at $\mathrm{NaCl}$ concentrations of $1-5 \%(\mathrm{w} / \mathrm{v})$, with optimum growth at $3 \%(\mathrm{w} / \mathrm{v})$.

Fatty acid methyl ester analysis with a GC/MS system (Hanada et al., 2002) revealed that the main cellular fatty acids of strain $\mathrm{St} 55 \mathrm{~B}^{\mathrm{T}}$ grown at $55^{\circ} \mathrm{C}$ were iso- $\mathrm{C}_{15: 0}(48 \%$ of total fatty acids) and anteiso- $\mathrm{C}_{15: 0}(13 \%)$. The strain also contained iso- $\mathrm{C}_{15: 1}(5 \%), \mathrm{C}_{16: 1}(6 \%)$, iso- $\mathrm{C}_{16: 0}(4 \%)$, iso- $\mathrm{C}_{17: 1}(6 \%)$ and two kinds of branched $\mathrm{C}_{17: 0}(18 \%)$ as minor components. All members of the genera Thermus, Meiothermus or Marinithermus contain predominantly iso- and anteiso-branched saturated fatty acids (Da Costa \& Rainey, 2001; Sako et al., 2003). The cellular fatty acids of strain $\mathrm{St} 55 \mathrm{~B}^{\mathrm{T}}$ consisted mainly of iso- and anteiso-branched, odd-carbon-numbered fatty acids, like other related species. The closest relative, $O$. profundus, is known to include significant amounts ( $33 \%$ of total fatty acids) of unsaturated fatty acids (Miroshnichenko et al., 2003a). While such a high content of unsaturated fatty acids is rarely observed in thermophilic bacteria, our fatty acid methyl ester analysis of $O$. profundus grown at $55^{\circ} \mathrm{C}$ also indicated that the related species clearly contains a large amount of them (approx. $37 \%$ ). In our isolate, strain $\mathrm{St} 55 \mathrm{~B}^{\mathrm{T}}$, unsaturated fatty acids such as iso- $\mathrm{C}_{15: 1}, \mathrm{C}_{16: 1}$ and iso- $\mathrm{C}_{17: 1}$ were also detected, but they represented only $18 \%$ of the total cellular fatty acids, equivalent to half that present in $O$. profundus. The fatty acid methyl ester profile of strain $\mathrm{St} 55 \mathrm{~B}^{\mathrm{T}}$ grown at $45^{\circ} \mathrm{C}$ was almost identical to that of cells grown at $55^{\circ} \mathrm{C}$. In general, the unsaturated fatty acid content tends to increase when cells are grown at lower temperatures, but the content in strain $\mathrm{St}_{5} 5 \mathrm{~B}^{\mathrm{T}}$ was stable even if it was grown at low temperatures.

MK- 8 was detected as the major quinone of strain $S t 55 B^{\mathrm{T}}$ by using HPLC (Shintani et al., 2000). Trace amounts of MK-6 $\left(\mathrm{H}_{2}\right), \mathrm{MK}-7, \mathrm{MK}-7\left(\mathrm{H}_{8}\right)$ and MK-9 were also detected. The genomic DNA G $+\mathrm{C}$ content (Mori et al., 2000) of strain St $55 \mathrm{~B}^{\mathrm{T}}$ was $71 \cdot 1 \mathrm{~mol} \%$. The $\mathrm{G}+\mathrm{C}$ content of the reference species, O. profundus, was $68.6 \mathrm{~mol} \%$ when measured by the same method, whereas the value reported by Miroshnichenko et al. (2003a) was $62.9 \mathrm{~mol} \%$.

Differential characteristics of $\mathrm{St} 55 \mathrm{~B}^{\mathrm{T}}$ are summarized in Table 1 in comparison with those of the most related species, O. profundus (Miroshnichenko et al., 2003a). $O$. profundus is a thermophilic, microaerophilic microorganism isolated from a deep-sea hydrothermal vent site in East Pacific Rise. The 16S rRNA gene sequence and also some phenotypic features were very similar to those of strain St $55 B^{\mathrm{T}}$. However, strain St $55 \mathrm{~B}^{\mathrm{T}}$ clearly differed from $O$. profundus in the following respects: (i) strain $\mathrm{St} 55 \mathrm{~B}^{\mathrm{T}}$ grew with nitrite as an electron acceptor under anaerobic conditions, unlike O. profundus; (ii) O. profundus utilized various sugars and alcohols, but strain $\mathrm{St} 55 \mathrm{~B}^{\mathrm{T}}$ was unable to use these substrates and preferred complex compounds such as yeast extract, tryptone and Casamino acids; (iii) the genomic DNA $\mathrm{G}+\mathrm{C}$ content differentiated the isolate $(71.1 \mathrm{~mol} \%)$ from O. profundus $(68.9 \mathrm{~mol} \%)$; (iv) the unsaturated fatty acid content of the isolate $(18 \%)$ was clearly lower than that in O. profundus (33-37\%); and (v) the $\mathrm{pH}$ for optimum growth of the isolate was slightly acid $(\mathrm{pH} \mathrm{6} \cdot 5)$.

The results of the DNA-DNA hybridization study (Tamaki et al., 2003) are also shown in Table 1. The DNA relatedness between strain $S t 55 \mathrm{~B}^{\mathrm{T}}$ and O. profundus was less than $20 \%$, suggesting strongly that these two organisms should be classified as different species (Wayne et al., 1987). For the reasons described above, we propose strain $\mathrm{St} 55 \mathrm{~B}^{\mathrm{T}}$ as a novel species with the name Oceanithermus desulfurans sp. nov.

A lot of bacteria able to use elemental sulfur in anaerobic respiration that have been isolated, including Caminibacter hydrogeniphilus (Alain et al., 2002a), Nautilia lithotrophica (Miroshnichenko et al., 2002), Desulfurobacterium thermolithotrophum (L'Haridon et al., 1998) and members of the genus Marinitoga (Alain et al., 2002b), are strictly anaerobic sulfur-reducing bacteria that live in deep-sea hydrothermal vents. Persephonella marina (Götz et al., 2002) and some strains in the $\varepsilon$-Proteobacteria (Takai et al., 2003) are facultatively anaerobic bacteria that are capable of reducing elemental sulfur. Members of the genus Oceanithermus can use elemental sulfur as an electron acceptor under anaerobic conditions, and this is the first report of a sulfur-reducer in the family Thermaceae. A shortage of oxygen easily occurs in deep-sea environments where reduced sulfur compounds are supplied constantly. The ability to reduce elemental sulfur is advantageous to Oceanithermus species under such conditions. Oceanithermus species may be significant contributors to the sulfur cycle in deep-sea hydrothermal vents.

\section{Emended description of the genus Oceanithermus Miroshnichenko et al. 2003}

Cells are non-motile, Gram-negative rods, and 'rotund bodies' are observed. Moderately thermophilic. Nonsporulating. Microaerophilic. Growth also occurs by anaerobic respiration with nitrate and elemental sulfur. Some species use nitrite as an electron acceptor. MK-8 is the major respiratory quinone. The major cellular fatty acids are iso- and anteiso-branched types. Unsaturated fatty acids were also detected (18-37\%). The genomic DNA G +C content is $62.9-71 \cdot 1 \mathrm{~mol} \%$. The phylogenetic position, based on 16S rRNA gene sequences, is in the family Thermaceae. The type species is Oceanithermus profundus.

\section{Description of Oceanithermus desulfurans sp. nov.}

Oceanithermus desulfurans (de.sul'fu.rans. N.L. part. adj. desulfurans making free of/reducing sulfur).

Cells are rods, about $0 \cdot 5 \mu \mathrm{m}$ wide and $1 \cdot 5-2 \cdot 0 \mu \mathrm{m}$ long, and 'rotund bodies' are observed under good growth conditions. Gram reaction is negative. Non-motile, non-pigmented and 


\section{Table 1. Characteristics of strain $\mathrm{St}_{5} 5 \mathrm{~B}^{\top}$ and O. profundus}

Data for O. profundus $506^{\mathrm{T}}$ were taken from Miroshnichenko et al. (2003a). +, Positive; -, negative. Cells of both taxa are rods, with the formation of 'rotund bodies', and the same results were obtained for both strains for the following characteristics: spore formation ( - ); pigmentation (-); Gram-staining (-); sensitivity to $\mathrm{O}_{2}$ (microaerophilic and anaerophilic); major respiratory quinone (MK-8); NaCl concentration for optimum growth $(3 \%, \mathrm{w} / \mathrm{v})$.

\begin{tabular}{|c|c|c|}
\hline Characteristic & Strain St55B $B^{T}$ & O. profundus $506^{\mathrm{T}}$ \\
\hline DNA G $+\mathrm{C}$ content $(\mathrm{mol} \%)$ & $71 \cdot 1$ & $68 \cdot 6^{*}$ \\
\hline Main fatty acids & iso- $\mathrm{C}_{15: 0}$, anteiso- $\mathrm{C}_{15: 0}$ & iso- $\mathrm{C}_{15: 0}$, iso- $\mathrm{C}_{16: 1}$ \\
\hline Unsaturated fatty acid content (\%) & 18 & $37^{\star}$ \\
\hline $\mathrm{pH}$ & $6 \cdot 5$ & $7 \cdot 5$ \\
\hline \multicolumn{3}{|l|}{ Electron acceptors: } \\
\hline $\mathrm{O}_{2}$ & + & + \\
\hline $\mathrm{NO}_{3}^{-}$ & + & + \\
\hline $\mathrm{NO}_{2}^{-}$ & + & - \\
\hline Casamino acids & + & - \\
\hline Fructose & - & + \\
\hline Galactose & - & + \\
\hline Glucose & - & + \\
\hline Sucrose & - & + \\
\hline Xylose & - & + \\
\hline Acetate & - & + \\
\hline Propionate & + & + \\
\hline Pyruvate & + & + \\
\hline Ethanol & - & + \\
\hline Methanol & - & + \\
\hline
\end{tabular}

${ }^{\star}$ Results for $\mathrm{G}+\mathrm{C}$ content, cellular fatty acids and utilization of elemental sulfur in O. produndus $506^{\mathrm{T}}$ were obtained in this study.

non-sporulating. Chemoheterotrophic. Microaerophilic and facultatively anaerophilic. Anaerobic growth occurs in the presence of elemental sulfur, nitrate or nitrite as an electron acceptor, but sulfate, thiosulfate, sulfite, DMSO, fumarate, $\mathrm{Fe}$ (III) citrate and selenate do not support growth. Yeast extract is necessary for growth. Yeast extract, tryptone, Casamino acids, butyrate, formate, glutamate, lactate, propionate, pyruvate, succinate, L-alanine and L-cysteine are used as carbon and energy sources. No growth occurs with $\mathrm{H}_{2} / \mathrm{CO}_{2}$, acetate $+\mathrm{H}_{2} / \mathrm{CO}_{2}$, arabinose, fructose, galactose, glucose, inositol, mannose, raffinose, sucrose, xylose, acetate, citrate, fumarate, malate, L-arginine, Lasparagine, L-histidine, L-leucine, L-methionine, L-serine, ethanol, 2-propanol or methanol. Grows at $30-65^{\circ} \mathrm{C}$; optimum growth is at $60^{\circ} \mathrm{C}$. The $\mathrm{pH}$ range for growth is $6 \cdot 0-8 \cdot 0$, with optimum growth at $\mathrm{pH} 6 \cdot 5$. Growth occurs at
$1-5 \%(\mathrm{w} / \mathrm{v}) \mathrm{NaCl}$ and the optimum growth concentration is $3 \%(\mathrm{w} / \mathrm{v})$. MK-8 is the major quinone. The major cellular fatty acid is iso- $\mathrm{C}_{15: 0}$. Unsaturated fatty acids $(18 \%)$ are also present. The genomic DNA G $+\mathrm{C}$ content is $71 \cdot 1 \mathrm{~mol} \%$.

The type strain is $\mathrm{St}_{55 \mathrm{~B}^{\mathrm{T}}}\left(=\mathrm{NBRC} 100063^{\mathrm{T}}=\mathrm{DSM}\right.$ $\left.15757^{\mathrm{T}}\right)$, isolated from a chimney in the Suiyo Seamount (at a depth of $1390 \mathrm{~m}$ ) in the Izu-Bonin Arc, Western Pacific.

\section{Acknowledgements}

We thank the scientific party, the operational team of the vessel ROV Hakuyo 2000 and the crew of work boat Shinsei-maru for collecting samples. We thank X.-Y. Meng (National Institute of Advanced Industrial Science and Technology) for operation of the electron microscope. The Ministry of Education, Science and Technology 
(MEST) of Japan funded this research through the Special Coordination Fund 'Archaean Park Project' (International Research Project on Interaction Between Sub-Vent Biosphere and Geo-Environments).

\section{References}

Alain, K., Querellou, J., Lesongeur, F., Pignet, P., Crassous, P., Raguénès, G., Cueff, V. \& Cambon-Bonavita, M.-A. (2002a). Caminibacter hydrogeniphilus gen. nov., sp. nov., a novel thermophilic, hydrogen-oxidizing bacterium isolated from an East Pacific Rise hydrothermal vent. Int J Syst Evol Microbiol 52, 1317-1323.

Alain, K., Marteinsson, V. T., Miroshnichenko, M. L., BonchOsmolovskaya, E. A., Prieur, D. \& Birrien, J.-L. (2002b). Marinitoga piezophila sp. nov., a rod-shaped, thermo-piezophilic bacterium isolated under high hydrostatic pressure from a deep-sea hydrothermal vent. Int J Syst Evol Microbiol 52, 1331-1339.

Brock, T. D. \& Edwards, M. R. (1970). Fine structure of Thermus aquaticus, an extreme thermophile. J Bacteriol 104, 509-517.

Corre, E., Reysenbach, A. L. \& Prieur, D. (2001). Epsilonproteobacterial diversity from a deep-sea hydrothermal vent on the Mid-Atlantic Ridge. FEMS Microbiol Lett 205, 329-335.

Da Costa, M. S. \& Rainey, F. A. (2001). Family I. Thermaceae fam. nov. In Bergey's Manual of Systematic Bacteriology: the Archaea and the Deeply Branching and Phototrophic Bacteria, 2nd edn, vol. 1, pp. 403-404. Edited by D. R. Boone \& R. W. Castenholz. New York: Springer.

DSMZ (1993). Catalogue of Strains, 5th edn. Braunschweig: Gesellschaft fur Biotechnologische Forschung.

Götz, D., Banta, A., Beveridge, T. J., Rushdi, A. I., Simoneit, B. R. T. \& Reysenbach, A.-L. (2002). Persephonella marina gen. nov., sp. nov. and Persephonella guaymasensis sp. nov., two novel, thermophilic, hydrogen-oxidizing microaerophiles from deep-sea hydrothermal vents. Int J Syst Evol Microbiol 52, 1349-1359.

Hanada, S., Takaichi, S., Matsuura, K. \& Nakamura, K. (2002). Roseiflexus castenholzii gen. nov., sp. nov., a thermophilic, filamentous, photosynthetic bacterium that lacks chlorosomes. Int J Syst Evol Microbiol 52, 187-193.

Hattori, S., Kamagata, Y., Hanada, S. \& Shoun, H. (2000). Thermacetogenium phaeum gen. nov., sp. nov., a strictly anaerobic, thermophilic, syntrophic acetate-oxidizing bacterium. Int J Syst Evol Microbiol 50, 1601-1609.

Heising, S., Richter, L., Ludwig, W. \& Schink, B. (1999). Chlorobium ferrooxidans sp. nov., a phototrophic green sulfur bacterium that oxidizes ferrous iron in coculture with a "Geospirillum" sp. strain. Arch Microbiol 172, 116-124.

Huber, H., Diller, S., Horn, C. \& Rachel, R. (2002). Thermovibrio ruber gen. nov., sp. nov., an extremely thermophilic, chemolithoautotrophic, nitrate-reducing bacterium that forms a deep branch within the phylum Aquificae. Int J Syst Evol Microbiol 52, 1859-1865.

Jeanthon, C., L'Haridon, S., Cueff, V., Banta, A., Reysenbach, A.-L. \& Prieur, D. (2002). Thermodesulfobacterium hydrogeniphilum sp. nov., a thermophilic, chemolithoautotrophic, sulfate-reducing bacterium isolated from a deep-sea hydrothermal vent at Guaymas Basin, and emendation of the genus Thermodesulfobacterium. Int J Syst Evol Microbiol 52, 765-772.

L'Haridon, S., Cilia, V., Messner, P., Raguénès, G., Gambacorta, A., Sleytr, U. B., Prieur, D. \& Jeanthon, C. (1998). Desulfurobacterium thermolithotrophum gen. nov., sp. nov., a novel autotrophic, sulphurreducing bacterium isolated from a deep-sea hydrothermal vent. Int J Syst Bacteriol 48, 701-711.

Marteinsson, V. T., Birrien, J. L., Kristjánsson, J. K. \& Prieur, D. (1995). First isolation of thermophilic aerobic non-sporulating heterotrophic bacteria from deep-sea hydrothermal vents. FEMS Microbiol Ecol 18, 163-174.
Miroshnichenko, M. L., Kostrikina, N. A., L'Haridon, S., Jeanthon, C., Hippe, H., Stackebrandt, E. \& Bonch-Osmolovskaya, E. A. (2002). Nautilia lithotrophica gen. nov., sp. nov., a thermophilic sulfurreducing $\varepsilon$-proteobacterium isolated from a deep-sea hydrothermal vent. Int J Syst Evol Microbiol 52, 1299-1304.

Miroshnichenko, M. L., L'Haridon, S., Jeanthon, C. \& 7 other authors (2003a). Oceanithermus profundus gen. nov., sp. nov., a thermophilic, microaerophilic, facultatively chemolithoheterotrophic bacterium from a deep-sea hydrothermal vent. Int J Syst Evol Microbiol 53, 747-752.

Miroshnichenko, M. L., L'Haridon, S., Nercessian, O. \& 8 other authors (2003b). Vulcanithermus mediatlanticus gen. nov., sp. nov., a novel member of the family Thermaceae from a deep-sea hot vent. Int J Syst Evol Microbiol 53, 1143-1148.

Mori, K., Yamamoto, H., Kamagata, Y., Hatsu, M. \& Takamizawa, K. (2000). Methanocalculus pumilus sp. nov., a heavy-metal-tolerant methanogen isolated from a waste-disposal site. Int J Syst Evol Microbiol 50, 1723-1729.

Nakagawa, S., Takai, K., Horikoshi, K. \& Sako, Y. (2003). Persephonella hydrogeniphila sp. nov., a novel thermophilic, hydrogenoxidizing bacterium from a deep-sea hydrothermal vent chimney. Int J Syst Evol Microbiol 53, 863-869.

Saitou, N. \& Nei, M. (1987). The neighbor-joining method: a new method for reconstructing phylogenetic trees. Mol Biol Evol 4, 406-425.

Sako, Y., Nakagawa, S., Takai, K. \& Horikoshi, K. (2003). Marinithermus hydrothermalis gen. nov., sp. nov., a strictly aerobic, thermophilic bacterium from a deep-sea hydrothermal vent chimney. Int J Syst Evol Microbiol 53, 59-65.

Shintani, T., Liu, W. T., Hanada, S., Kamagata, Y., Miyaoka, S., Suzuki, T. \& Nakamura, K. (2000). Micropruina glycogenica gen. nov., sp., nov., a new Gram-positive glycogen-accumulating bac!terium isolated from activated sludge. Int J Syst Evol Microbiol 50, 201-207.

Takai, K. \& Horikoshi, K. (1999). Genetic diversity of archaea in deep-sea hydrothermal vent environments. Genetics 152, 1285-1297. Takai, K., Komatsu, T., Inagaki, F. \& Horikoshi, K. (2001). Distribution of archaea in a black smoker chimney structure. Appl Environ Microbiol 67, 3618-3629.

Takai, K., Inagaki, F., Nakagawa, S., Hirayama, H., Nunoura, T., Sako, Y., Nealson, K. H. \& Horikoshi, K. (2003). Isolation and phylogenetic diversity of members of previously uncultivated epsilon-Proteobacteria in deep-sea hydrothermal fields. FEMS Microbiol Lett 218, 167-174.

Tamaki, H., Hanada, S., Kamagata, Y., Nakamura, K., Nomura, N., Nakano, K. \& Matsumura, M. (2003). Flavobacterium limicola sp. nov., a psychrophilic, organic-polymer-degrading bacterium isolated from freshwater sediments. Int J Syst Evol Microbiol 53, 519-526.

Thompson, J. D., Higgins, D. G. \& Gibson, T. J. (1994). CLUSTAL W: improving the sensitivity of progressive multiple sequence alignment through sequence weighting, position-specific gap penalties and weight matrix choice. Nucleic Acids Res 22, 4673-4680.

Vetriani, C., Speck, M. D., Ellor, S. V., Lutz, R. A. \& Starovoytov, V. (2004). Thermovibrio ammonificans sp. nov., a thermophilic, chemolithotrophic, nitrate-ammonifying bacterium from deep-sea hydrothermal vents. Int J Syst Evol Microbiol 54, 175-181.

Wayne, L. G., Brenner, D. J., Colwell, R. R. \& 9 other authors (1987). International Committee on Systematic Bacteriology. Report of the ad hoc committee on reconciliation of approaches to bacterial systematics. Int J Syst Bacteriol 37, 463-464.

Wery, N., Lesongeur, F., Pignet, P., Derennes, V., Cambon-Bonavita, M.-A., Godfroy, A. \& Barbier, G. (2001). Marinitoga camini gen. nov., sp. nov., a rod-shaped bacterium belonging to the order Thermotogales, isolated from a deep-sea hydrothermal vent. Int J Syst Evol Microbiol 51, 495-504. 